\title{
Hypoglycemic Activity of Some Kenyan Plants Traditionally used to Manage Diabetes Mellitus in Eastern Province
}

\author{
Ngugi M Piero ${ }^{1 *}$, Murugi N Joan ${ }^{1}$, Kibiti M Cromwell ${ }^{1}$, Ngeranwa J Joseph$^{1}$, Njue M Wilson², Maina Daniel ${ }^{3}$, Gathumbi K Peter ${ }^{4}$ and Njagi N \\ Eliud $^{1}$
}

${ }^{1}$ Department of Biochemistry and Biotechnology, Kenyatta University, Nairobi, Kenya

${ }^{2}$ Department of Chemistry, Kenyatta University, Nairobi, Kenya

${ }^{3}$ Institute of Nuclear Science, University of Nairobi, Nairobi, Kenya

${ }^{4}$ Department of Veterinary Pathology, Microbiology and Parasitology, University of Nairobi, Nairobi, Kenya

\begin{abstract}
In this study five aqueous extracts; Bidens pilosa, Strychnos henningsii, Aspilia pluriseta, Catha edulis and Erythrina abyssinica were screened for anti-diabetic activity and their in vivo safety evaluated. The anti-diabetic activity was assessed by intraperitoneally injecting varying doses of aqueous extracts of the five plants into alloxanised mice. Toxicity was determined by injecting normal mice with $450 \mathrm{mg}$ of the plant extract / $\mathrm{kg}$ body weight and observing the effects of the extracts on histology of various organs. All the extracts showed hypoglycaemic activity. At high doses, some plants proved to be highly toxic, mildly toxic and others were safe. This study has established that the five bioactive plants can be safely used in the management of diabetes.
\end{abstract}

Keywords: Anti-diabetic activity; in vivo toxicity; Histology; Alloxanised mice

\section{Introduction}

Diabetes mellitus is a chronic endocrinological disorder characterized by high blood levels of glucose due to insufficient secretion of insulin by the pancreas or improper utilization of insulin by target cells [1]. Diabetes can be associated with serious complications and premature death, but people with diabetes mellitus can take steps to control the disease and lower the risk of complications [2].

The incidence of diabetes mellitus (DM) has reached an alarming level despite having been a rare disease 50 years ago, attaining a global incidence of 151 million people per year [3,4]. In 1997 the World Health Organization issued a report that predicted the number of diagnosed cases of DM would rise from 125 million in 1995 to an estimated 300 million in 2025 [3]. The number per country varies greatly. In Africa, the DM is projected to rise from 9 million people in 2000 to 14 million people in 2010 [5]. In Kenya, it is estimated that 190,400 people in the 20-79 age group suffer from diabetes mellitus (www.idf.org, 2003)

There are two types of diabetes mellitus; type 1 or insulin dependent diabetes mellitus (IDDM) and type 2 or non-insulin dependent diabetes mellitus (NIDDM). Other forms of diabetes mellitus include secondary diabetes and gestational diabetes. However, it should be noted that assigning a type of diabetes to an individual often depends on the prevailing circumstances at the time of diagnosis, and many diabetic individuals do not easily fit into a single class. For example, a person with gestational diabetes mellitus (GDM) may continue to be hyperglycemic after delivery and may be destined to have type II diabetes. Similarly, a person who acquires diabetes because of large doses of exogenous steroids may become normoglycemic once the glucocorticoids are discontinued, but then may develop diabetes many years later after recurrent episodes of pancreatitis [6].

The principle complications of diabetes mellitus are retinopathy, neuropathy, nephropathy, angiopathy, susceptibility to infections, hyperlipidemia, ketoacidosis, and hyperglycaemic hyperosmolar non-ketonic coma (HHNC). These complications result in increased disability, reduced life expectancy and enormous health cost for virtually every society $[7,8]$.
The major therapy option in diabetes mellitus is lifestyle management. Besides exercise, weight control and medical nutrition therapy, oral glucose-lowering drugs and insulin injection are the conventional therapies for the disease [9]. These conventional therapies have adverse side effects, are expensive and require expertise.

There is a new trend in the world to turn back to natural substances as alternatives to synthetic drugs either due to cost factorsd or to summount the side effects of the former [10]. Less than a quarter of the estimated 250,000 medicinal plant species have been investigated for hypoglycemic activity. Herbal medicines are cheap, more readily available to people but a lot needs to be done to establish their safety, which in common practice is presumed from historical traditional use. Besides, many plants are being rendered extinct by human activity, which makes it necessary to study them before they become extinct and advocate for their conservation; aside from the disintegration of traditional knowledge on their use with changing culture. This study, therefore, sought to screen selected medicinal plants used in treatment of diabetic mellitus by traditional medicine practitioners in Kenya for their hypoglycemic activity and safety.

\section{Materials and Methods}

\section{Collection of the plants}

The plants used in this study were collected from their natural habitats on the basis of ethnobotanical information. They were collected with bioconservation aspects in mind from Gachoka

*Corresponding author: Ngugi M Piero, Department of Biochemistry and Biotechnology, Kenyatta University, Nairobi, Kenya, Tel: 810901/811278; E-mail: matpiero@gmail.com

Received July 21, 2011; Accepted November 19, 2011; Published Novembe 24, 2011

Citation: Piero NM, Joan MN, Cromwell KM, Joseph NJ, Wilson NM, et al. (2011) Hypoglycemic Activity of Some Kenyan Plants Traditionally used to Manage Diabetes Mellitus in Eastern Province. J Diabetes Metab 2:155. doi:10.4172/21556156.1000155

Copyright: ( 2011 Piero NM, et al. This is an open-access article distributed unde the terms of the Creative Commons Attribution License, which permits unrestricted use, distribution, and reproduction in any medium, provided the original author and source are credited. 
division of Mbeere district in Kenya. An acknowledged authority in taxonomy authenticated the botanical identity of the plants and a voucher specimen was deposited at the National Museums of Kenya Herbarium, Nairobi. The plants collected and studied were Bidens pilosa, Erythrina abyssinica, Aspilia pluriseta, Strychnos henningsii and Catha edulis. The voucher specimen numbers for the collected and studied plants are Hypogly 001/2004 (Bidens pilosa), Hypogly 021/2004 (Erythrina abyssinica), Hypogly 003/2004 (Aspilia pluriseta), Hypogly 004/2004 (Strychnos henningsii) and Hypogly 005/2004 (Catha edulis). A traditional medical practitioner provided the information on which plant to collect, what part to collect, the precise locality where it grows, when curative potency is maximal and the mode of preparation.

\section{Initial processing of the plants for extraction}

The parts of the plants collected were root barks, stem barks or leaves. The stems and roots were harvested and their barks peeled off while still fresh, cut into small pieces and then dried at room temperature for different periods of time depending on the succulence of the plant materials. Leaves were collected while green and dried in the same way. The root barks, stem barks and the leaves were separately ground when completely dry using an electric mill. The powdered plant materials were kept at room temperature away from direct sunlight in closed dry plastic bags.

Extraction: $100 \mathrm{~g}$ of each powdered plant material was boiled in one liter of distilled water for 2 hours. After boiling, the solution was allowed to cool. The extract was then decanted into a 1-litre clean dry conical flask and filtered through a No. 1 Whatman filter paper under vacuum pump into a $500 \mathrm{ml}$ clean dry conical flask. Decantation and filtration processes were repeated until the sample became clear. The filtrate was centrifuged at 3000 RPM for 5 minutes and the supernate freeze-dried, weighed and stored in an airtight container until used for bioassay [11].

Preparation of extracts for injection into mice: The freeze-dried plant extracts were prepared for injection into mice as follows: The $50 \mathrm{mg} / \mathrm{kg}$ body weight dose was prepared by dissolving $12.5 \mathrm{mg}$ in $1 \mathrm{ml}$ of physiological saline, the $100 \mathrm{mg} / \mathrm{kg}$ body weight dose was prepared by dissolving $25 \mathrm{mg}$ in $1 \mathrm{ml}$ of physiological saline, and the $150 \mathrm{mg} / \mathrm{kg}$ body weight dose was prepared by dissolving $37.5 \mathrm{mg}$ in $1 \mathrm{ml}$ of physiological saline. $0.1 \mathrm{ml}$ of the prepared solutions was used for injection.

Animals and experimental design: The experimental animals used in this study were Swiss albino male mice weighing 23-27g. The animals they were bred in the Department of Biochemistry and Biotechnology, Kenyatta University Animal house. They received a standard pellet diet and water ad libitum. The mice were acclimatized to handlers for 3 days before the start of the experiments. Animals described as fasted were deprived of food for $16 \mathrm{hr}$ before the start of bioassay but had free access to water. The mice were sub-divided into 4 groups: Group I (untreated mice) was given $0.1 \mathrm{ml}$ of normal saline; Group II, (diabetic mice) was given $0.1 \mathrm{ml}$ of normal saline; Group III, (diabetic mice) was given insulin at a dose of $1 \mathrm{IU} / \mathrm{kg}$ body weight; and Group IV, (diabetic mice) was given plant extracts at three dose levels $(50 \mathrm{mg} /$ $\mathrm{kg}$ body weight, $100 \mathrm{mg} / \mathrm{kg}$ body weight and $150 \mathrm{mg} / \mathrm{kg}$ body weight). Diabetic condition was induced in mice by intraperitoneal injection of alloxan monohydrate $(150 \mathrm{mg} / \mathrm{kgbw}) 72$ hours before the start of experiment. Group I and II served as controls while group III served as the reference. Each group consisted of 4 animals, but in group IV, each dose level was given to 4 animals.

Collection of blood samples: Blood was obtained from the tails of the mice by snipping the tips with sterile scissors, which had first been sterilized by swabbing with $70 \%$ ethanol. Bleeding was then enhanced by gently "milking" the tail from the body towards the tip. After the operation, the tips of the tail were again sterilized by swabbing with $70 \%$ ethanol.

Blood sugar determination: The blood sugar level in the mice was determined by using Hypoguard Supreme Glucometer. Strips compatible with the glucometer that were appropriately inserted in the glucometer and blood from the tail of the mice was placed on the glucometer strip. The blood glucose level was read on glucometer screen in $\mathrm{mg} / \mathrm{dL}$. Supreme Hypoguard glucometer works on the principle of glucose oxidase assay [12].

In vivo antihyperglycemic activity assay: The animals were treated with the physiological saline, insulin and the plant extracts as previously described (2.3). The blood glucose level was first taken as previously described (2.3.1) before treatment. After treatment, the blood was collected after 1 hour, 2 hours, 3 hours and 4 hours. The blood glucose level was determined after every blood collection. During the experiment, the animals continued to be fasted but were allowed free access to water.

\section{Phytochemical screening}

Plants extracts were screened for classes of secondary metabolites, which included alkaloids, saponins, tannins, triterpenes, and sterols, flavonoids and anthraquinones using standard methods as described by Houghton and Raman, (1998) [13].

\section{Preliminary in vivo toxicity evaluation}

For determination of toxicity of plant extracts in normal mice, the mice were divided into two groups. Group I served as a control. It was treated with $0.1 \mathrm{ml}$ of physiological saline. Group II was treated with the extract. Each mouse in this group was intraperitoneally injected with the extracts at a dose of $450 \mathrm{mg} / \mathrm{kgbw}$ daily for one month. The animals were kept under close observation and fed on pellet diet and water ad libitum. At the end of thirty (30) days, the mice were sacrificed and postmortem examination performed and samples of liver, kidney, heart, lungs, and muscles collected and preserved in 10\% neutral buffered formalin and processed for histological examination

\section{Data analysis}

The experimental data was analyzed using unpaired Student t-test. This test determined whether there were any significant differences between the data obtained in plant extract, placebo and insulin treated groups. A $\mathrm{P}<0.05$ was considered significant. Instat statistical computer software was used.

\section{Results}

\section{In vivo hypoglycemic assays}

For all the in vivo hypoglycemic assay results, all values are expressed as Mean \pm SEM for four animals per group, ${ }^{a} \mathrm{p}<0.05$ versus normal control, ${ }^{b} \mathrm{p}<0.05$ versus diabetic control and ${ }^{c} \mathrm{p}<0.05$ versus diabetic insulin.

In the third hour, the B. pilosa extract, at dose levels of 100 and $150 \mathrm{mg} / \mathrm{kg}$ body weight, lowered the blood glucose levels to normal and were as effective as insulin $\left({ }^{b} p<0.05 ;{ }^{c} p<0.05\right)$. Up to the fourth hour, the three dose levels maintained the blood glucose levels at normal and all but the dose level of $50 \mathrm{mg} / \mathrm{kg}$ body weight were as effective as insulin [Table 1]. 
Citation: Piero NM, Joan MN, Cromwell KM, Joseph NJ, Wilson NM, et al. (2011) Hypoglycemic Activity of Some Kenyan Plants Traditionally used to Manage Diabetes Mellitus in Eastern Province. J Diabetes Metab 2:155. doi:10.4172/2155-6156.1000155

The dose levels of 100 and $150 \mathrm{mg} / \mathrm{kg}$ body weight of the stem bark extracts of E. abyssinica lowered the blood glucose levels in alloxan induced diabetic mice in the third hour to normal and were as effective as insulin. The same case was observed with this dose level in the fourth hour $\left({ }^{a} \mathrm{p}<0.05 ;{ }^{c} \mathrm{p}<0.05\right)$. In the fourth hour, the three dose levels maintained the blood glucose level at normal and all but the dose level of $50 \mathrm{mg} / \mathrm{kg}$ body weight were as effective as insulin [Table 2].

In the first hour it was also observed that the root extract of $A$. pluriseta, at dose levels of 50 and $100 \mathrm{mg} / \mathrm{kg}$ body weight, lowered the blood glucose levels appreciably but not as effectively as insulin. This was unlike the dose level of $150 \mathrm{mg} / \mathrm{kg}$ body weight, which lowered the blood glucose level to normal and was as effectively as insulin [Table 3]. In the second hour, the dose level of $50 \mathrm{mg} / \mathrm{kg}$ body weight lowered the blood glucose level significantly. As table 3 shows, the dose level of $150 \mathrm{mg} / \mathrm{kg}$ body weight lowered the blood glucose level to even below normal. The extract continued lowering the blood glucose levels in a dose-dependent manner in the third and fourth hours.

The aqueous leaf extracts of $S$. henningsii, at the dose levels of 100 and $150 \mathrm{mg} / \mathrm{kg}$ body weight, lowered blood glucose levels to normal and were as effective as insulin. This trend was maintained up to the fourth hour [Table 4].

In the first hour, the root bark extract of C. edulis, at the dose level of $150 \mathrm{mg} / \mathrm{kg}$ body weight, lowered blood glucose level to normal and was as effective as insulin as opposed to the other lower dose levels. In the second hour, the dose level of $100 \mathrm{mg} / \mathrm{kg}$ body weight lowered the blood sugar level to normal and was as effective as insulin. At this hour, the dose level of $150 \mathrm{mg} / \mathrm{kg}$ body weight lowered blood glucose level to below normal an effect that was higher than in insulin treated group and this level was also lower than that of the normal mice. In the third and fourth hours, the dose levels of 100 and $150 \mathrm{mg} / \mathrm{kg}$ body weight were as effective as insulin $\left({ }^{b} \mathrm{p}<0.05\right)$ [Table 5].

\section{Phytochemical screening}

A number of classes of compounds were found in the aqueous extracts of B. pilosa, A. pluriseta, E. abyssinica, C. edulis and S. henningsii. As table 6 shows, $B$. pilosa aqueous leaves extract contained alkaloids, saponins, flavonols, flavones, flavonoids, chalcones, tannins, bound anthraquinones and trace amounts of sterols. A. pluriseta aqueous root bark extract contained flavonols, flavones, flavonoids, chalcones, tannins, and bound anthraquinones and trace amounts of sterols. E. abyssinica stem bark extract contained saponins, flavonols, flavones, flavonoids, chalcones and tannins. C. edulis aqueous root bark extract contained terpenoids, saponins, flavonols, flavones, flavonoids, chalcones, tannins, free anthraquinones and bound anthraquinones. The aqueous leaves extract of $S$. henningsii contained alkaloids, saponins, flavonols, flavones, flavonoids, chalcones, tannins, bound anthraquinones and trace amounts of sterols.

\begin{tabular}{|l|l|l|l|l|l|}
\hline Animal Group & Treatment & $\mathbf{0 ~ h r}$ & $\mathbf{1} \mathbf{~ h r}$ & $\mathbf{2} \mathbf{~ h r}$ & $\mathbf{3} \mathbf{~ h r}$ \\
\hline Normal Control & Normal Saline & $60.5 \pm 1.3$ & $60.0 \pm 2.0$ & $59.0 \pm 3.8$ & $58.5 \pm 3.4$ \\
\hline Diabetic Control & Normal Saline & $143.3 \pm 5.7$ & $155.8 \pm 8.8$ & $177.5 \pm 9.9$ & $196.8 \pm 7.9$ \\
\hline Diabetic +Insulin & $1 \mathrm{lU}$ & $164.0 \pm 8.9$ & $66.3 \pm 5.1$ & $52.0 \pm 2.3$ & $47.0 \pm 3.2$ \\
\hline Diabetic + B.pilosa & $50 \mathrm{mg} / \mathrm{kgbw}$ & $130.3 \pm 14.2$ & $101.8 \pm 19.9^{\mathrm{abc}}$ & $96.5 \pm 9.8^{\mathrm{abc}}$ & $88.8 \pm 10.3^{\mathrm{abc}}$ \\
\hline Diabetic+ B.pilosa & $100 \mathrm{mg} / \mathrm{kgbw}$ & $136.3 \pm 18.1$ & $141.8 \pm 11.9^{\mathrm{ac}}$ & $87.8 \pm 6.6^{\text {abc }}$ & $69.5 \pm 19.7^{\mathrm{bc}}$ \\
\hline Diabetic+ B.pilosa & $150 \mathrm{mg} / \mathrm{kgbw}$ & $191.0 \pm 16.6$ & $236.8 \pm 52.5^{\mathrm{abc}}$ & $88.0 \pm 7.2^{\text {abc }}$ & $55.3 \pm 4.49^{\mathrm{b}}$ \\
\hline
\end{tabular}

Table 1: Effect of Bidens pilosa on blood glucose in alloxan-induced diabetic mice.

\begin{tabular}{|c|c|c|c|c|c|c|}
\hline Animal Group & Treatment & $0 \mathrm{hr}$ & $1 \mathrm{hr}$ & $2 \mathrm{hr}$ & $3 \mathrm{hr}$ & $4 \mathrm{hr}$ \\
\hline Normal Control & Normal Saline & $60.8 \pm 3.3$ & $59.5 \pm 23.1$ & $56.3 \pm 0.8$ & $56.3 \pm 1.0$ & $53.0 \pm 1.9$ \\
\hline Diabetic Control & Normal Saline & $193.3 \pm 6.6$ & $214.8 \pm 7.6$ & $228.3 \pm 8.0$ & $235.3 \pm 6.5$ & $247.0 \pm 12.0$ \\
\hline Diabetic +Insulin & $1 I U$ & $198.0 \pm 8.8$ & $59.8 \pm 2.9$ & $54.3 \pm 2.3$ & $52.0 \pm 2.2$ & $49.0 \pm 2.3$ \\
\hline Diabetic + E.abyssnica & $50 \mathrm{mg} / \mathrm{kgbw}$ & $161.1 \pm 18.1$ & $184.5 \pm 13.5^{\mathrm{ac}}$ & $28.3 \pm 11.5^{\mathrm{abc}}$ & $100.5 \pm^{\mathrm{abc}}$ & $90.0 \pm 5.6^{\mathrm{abc}}$ \\
\hline Diabetic+ E.abyssnica & $100 \mathrm{mg} / \mathrm{kgbw}$ & $130.8 \pm 5.4$ & $171.8 \pm 19.2^{\mathrm{ac}}$ & $94.5 \pm 3.1^{\mathrm{abc}}$ & $70.8 \pm 8.4^{b}$ & $54.0 \pm 2.2^{\mathrm{b}}$ \\
\hline Diabetic+ E.abyssnica & $150 \mathrm{mg} / \mathrm{kgbw}$ & $231.0 \pm 59.6$ & $235.5 \pm 222^{\mathrm{ac}}$ & $89.5 \pm 13.7^{\mathrm{abc}}$ & $62.0 \pm 4.5^{b}$ & $46.8 \pm 3.7^{b}$ \\
\hline
\end{tabular}

Table 2: Effect of Erythrina abyssinica on blood glucose in alloxan-induced diabetic.

\begin{tabular}{|l|l|l|l|l|l|}
\hline Animal Group & Treatment & $\mathbf{0 ~ h r}$ & $\mathbf{1 ~ h r}$ & $\mathbf{2} \mathbf{~ h r}$ & $\mathbf{3} \mathbf{~ h r}$ \\
\hline Normal Control & Normal Saline & $61.3 \pm 1.7$ & $58.3 \pm 1.7$ & $58.8 \pm 1.5$ & $58.5 \pm 1.7$ \\
\hline Diabetic Control & Normal Saline & $148.8 \pm 24.3$ & $161.8 \pm 25.8$ & $184.5 \pm 22.1$ & $208.0 \pm 14.5$ \\
\hline Diabetic +Insulin & $1 \mathrm{U}$ & $159.8 \pm 6.3$ & $60.8 \pm 1.8$ & $220 \pm 16.1$ & $56.3 \pm 2.5$ \\
\hline Diabetic + A.pluriseta & $50 \mathrm{mg} / \mathrm{kgbw}$ & $142.8 \pm 13.9$ & $106.8 \pm 13.8^{\mathrm{ac}}$ & $90.3 \pm 7.0^{\mathrm{abc}}$ & $82.3 \pm 2.8$ \\
\hline Diabetic+ A.pluriseta & $100 \mathrm{mg} / \mathrm{kgbw}$ & $189.3 \pm 24.2$ & $95.5 \pm 4.1^{\mathrm{abc}}$ & $82.5 \pm 6.9^{\mathrm{abc}}$ & $73.0 \pm 4.4$ \\
\hline Diabetic+A.pluriseta & $150 \mathrm{mg} / \mathrm{kgbw}$ & $157.3 \pm 2.4$ & $59.8 \pm 1.5^{\mathrm{b}}$ & $56.5 \pm 1.8^{\mathrm{b}}$ & $77.5 \pm 5.6^{\mathrm{abc}}$ \\
\hline
\end{tabular}

Table 3: Effect of Aspilia pluriseta on blood glucose in alloxan-induced diabetic mice.

\begin{tabular}{|l|l|l|l|l|l|}
\hline Animal Group & Treatment & $\mathbf{0 ~ h r}$ & $\mathbf{1 ~ h r}$ & $\mathbf{2} \mathbf{~ h r}$ & $\mathbf{3} \mathbf{~ h r}$ \\
\hline Normal Control & Normal Saline & $58.3 \pm 2.6$ & $56.8 \pm 1.8$ & $54.3 \pm 1.3$ & $55.0 \pm 1.5$ \\
\hline Diabetic Control & Normal Saline & $208.5 \pm 35.7$ & $223.8 \pm 37.4$ & $255.8 \pm 37.9$ & $265.3 \pm 36.9$ \\
\hline Diabetic +Insulin & $1 \mathrm{U}$ & $200.8 \pm 6.6$ & $60.8 \pm 2.6$ & $56.0 \pm 1.1$ & $53.8 \pm 0.9$ \\
\hline Diabetic+S.henningsii & $50 \mathrm{mg} / \mathrm{kgbw}$ & $252.5 \pm 7.9$ & $190.5 \pm 8.4^{\mathrm{abc}}$ & $150.8 \pm 6.5^{\mathrm{abc}}$ & $139.0 \pm 3.7^{\mathrm{abc}}$ \\
\hline Diabetic+S.henningsii & $100 \mathrm{mg} / \mathrm{kgbw}$ & $157.8 \pm 39.3$ & $78.0 \pm 5.5^{\mathrm{abc}}$ & $70.8 \pm 5.3^{\mathrm{abc}}$ & $57.5 \pm 3.9^{\mathrm{b}}$ \\
\hline Diabetic+S.henningsii & $150 \mathrm{mg} / \mathrm{kgbw}$ & $131.3 \pm 10.4$ & $83.0 \pm 4.9^{\mathrm{abc}}$ & $65.3 \pm 3.4^{\mathrm{abc}}$ & $52.0 \pm 1.3$ \\
\hline
\end{tabular}

Table 4: Effect of Strychnos henningsii on blood glucose in alloxan-induced diabetic mice. 
Citation: Piero NM, Joan MN, Cromwell KM, Joseph NJ, Wilson NM, et al. (2011) Hypoglycemic Activity of Some Kenyan Plants Traditionally used to Manage Diabetes Mellitus in Eastern Province. J Diabetes Metab 2:155. doi:10.4172/2155-6156.1000155

\section{Preliminary histological assessment of toxicity in vivo}

The liver from the mice treated with the aqueous leaf extracts of $B$. pilosa showed preserved hepatocytes, which often had mild vacuolar degeneration The other tissues had no pathology. Spleen of the mice treated with the aqueous root bark extract of $A$. pluriseta displayed moderate lymphoid depopulation, while the other tissues were normal. There was reduction in lymphoid population in the spleen of the mice treated with the aqueous stem bark extract of E. abyssinica). The liver had prominent blood capillaries due to congestion, but the hepatocytes were not affected. The renal epithelial cells showed prominent cellular atrophy. There were occasional amorphous deposits in the lumen of the kidney tubules, which suggested nephrosis. All the other tissues were normal. The mice treated with the aqueous root bark extract of $C$. edulis displayed congestion of blood vessels occurred in the kidneys, while the other tissues were intact. The spleen of the mice treated with the aqueous leaf extract of $S$. henningsii had mild lymphoid depopulation. The perirenal fat tissues suffered mild steatitis in one case but the nephrons were intact. The other tissues were normal.

\section{Discussion}

The lowering of blood glucose levels in alloxan-induced diabetic mice by the aqueous leaf extracts of B. pilosa and $S$. henningsii, stem bark extracts of E. abyssinica, root bark extracts of A. pluriseta and $C$. edulis, indicates that these plants possess hypoglycaemic activity. That these plant extracts demonstrated varying degrees of the hypogylcemic action at the three different dose levels along a method that agrees with that used by [14] who demonstrated a dose related blood glucose lowering effect by the fresh juices of leaves of Catharanthus roseus Linn in normal and alloxan-induced diabetic rabbits. In addition, Kimura et al. (1999) using a similar method also observed a reduction in blood glucose levels after intraperitoneal administration of ginseng root extract in genetically obese diabetic KK-CAy mice.

Besides, the hypoglycaemic action of the extracts tested in this study could be attributed to the presence of flavonoids, flavones, flavonols, terpenoids and bound anthraquinones, which have been shown to be hypoglycaemic. A flavonoid-rich fraction isolated from guava (Psidium guajava) leaves given at a daily dose of 7.2-14.4g lowered blood glucose in humans [15]. The presence of saponins in this extract could also be responsible for the hypogycemic activity. For instance ginseng and its saponins have been shown to lower blood glucose in alloxan-treated, genetically diabetic, and normal mice [15]. In elderly patients with hyperglycemia, saponins also reduced serum glucose [16]. Terpenoids from the leaf extracts of Alisma plantago-aquatica have been shown to lower blood glucose in rats. Anthraquinones in root bark extracts of Salvia miltiorrhiza have been shown to prolong the hypoglycaemic effect in diabetic mice $[17,18]$. In addition, the presence of alkaloids in the aqueous leave extracts of B. pilosa and S. henningsii could also be responsible for the hypoglycaemic activity [Table 6]. In their study, [19] found that the neem seed kernel powder contained hypoglycaemic alkaloids that lowered blood sugar levels in alloxan-induced diabetic rabbits.

That these aqueous plant extracts (B. pilosa, E.abyssinica, A. pluriseta, S.henningsii and C. edulis) lowered blood glucose to normal and as effectively as insulin and at times beyond the lowering effect of insulin. This could imply that these extracts may be acting through multiple mechanisms commensurate with the different chemical groups in each extract. This is in agreement with the findings of [14], who observed that $C$. roseus fresh leaves juice had a more potent action than glibenclamide at some hour intervals after administration. The extracts may have produced hypoglycaemic action by being insulinomimetic. This is the mode of action of some oral hypoglycaemic agents such as phenformin (a biguanide), which produce hypoglycaemic activity by decreasing hepatic gluconeogenesis, increasing skeletal muscle glucose uptake, and reducing plasma triacylglycerols [20,21].

The extracts may also have lowered the blood glucose levels in mice by stimulating glucose catabolising enzymes and inhibiting

\begin{tabular}{|l|l|l|l|l|l|}
\hline Animal Group & Treatment & $\mathbf{0 ~ h r}$ & $\mathbf{1 ~ h r}$ & $\mathbf{2} \mathbf{~ h r}$ & $\mathbf{3} \mathbf{~ h r}$ \\
\hline Normal Control & Normal Saline & $67.0 \pm 5.0$ & $64.3 \pm 3.9$ & $63.8 \pm 3.4$ & $61.5 \pm 3.6$ \\
\hline Diabetic Control & Normal Saline & $117.3 \pm 8.4$ & $132.0 \pm 8.2$ & $148.0 \pm 10.2$ & $165.0 \pm 11.3$ \\
\hline Diabetic +Insulin & $1 \mathrm{UU}$ & $180.0 \pm 6.6$ & $69.8 \pm 5.2$ & $59.3 \pm 2.0$ & $48.0 \pm 3.8$ \\
\hline Diabetic+C.edulis & $50 \mathrm{mg} / \mathrm{kgbw}$ & $142.0 \pm 21.2$ & $94.8 \pm 1.1^{\text {abc }}$ & $127.5 \pm 1.9^{\text {ac }}$ & $147.5 \pm 12.5^{\mathrm{ac}}$ \\
\hline Diabetic+C.edulis & $100 \mathrm{mg} / \mathrm{kgbw}$ & $139.8 \pm 7.1$ & $85.3 \pm 1.2^{\text {abc }}$ & $62.8 \pm 1.5^{\text {bde }}$ & $54.0 \pm 0.2^{\mathrm{b}}$ \\
\hline Diabetic+C.edulis & $150 \mathrm{mg} / \mathrm{kgbw}$ & $181.0 \pm 6.4$ & $80.0 \pm 5.5^{\text {bde }}$ & $46.8 \pm 2.3^{\text {abc }}$ & $40.3 \pm 1.9^{\mathrm{ab}}$ \\
\hline
\end{tabular}

Table 5: Effect of Catha edulis on blood glucose in alloxan-induced diabetic mice.

\begin{tabular}{|c|c|c|c|c|c|}
\hline \multirow[b]{2}{*}{ Class of compound } & \multicolumn{5}{|c|}{ Plants and Parts } \\
\hline & $\begin{array}{l}L \\
\text { Bidens pilosa }\end{array}$ & $\begin{array}{l}R B \\
\text { Asplia pluriseta }\end{array}$ & $\begin{array}{l}\text { SB } \\
\text { Erythrinia abyssinica }\end{array}$ & $\begin{array}{l}\text { RB } \\
\text { Catha edulis }\end{array}$ & $\begin{array}{l}\text { L } \\
\text { Strychnos henningsii }\end{array}$ \\
\hline Alkaloids & + & - & - & - & + \\
\hline Sterols & $+($ trace $)$ & $+($ trace $)$ & - & - & $+($ trace $)$ \\
\hline Terpenoids & - & - & - & + & - \\
\hline Saponins & + & - & + & + & + \\
\hline Flavonols & + & + & + & + & + \\
\hline Flavones & + & + & + & + & + \\
\hline Chalcones & + & + & + & + & + \\
\hline Flavonoids & + & + & + & + & + \\
\hline Tannins & + & + & + & + & + \\
\hline Free Anthraquinones & - & - & - & + & - \\
\hline Bound Anthraquinones & + & + & - & + & + \\
\hline
\end{tabular}

Key: $+\rightarrow$ Positive $-\rightarrow$ Negative $+\quad($ trace $) \rightarrow$ Slightly positive $\mathrm{L} \rightarrow$ Leaf $\mathrm{RB} \rightarrow$ Root bark SB $\rightarrow$ Stem bark

Table 6: Phytochemistry of the five medicinal plants. 
gluconeogenic enzymes as was seen by [22], who observed the same mode of action by C.roseus in streptozotocin-induced diabetic rats. Alloxan causes a massive destruction of the $\beta$-cells resulting in reduced synthesis and release of insulin [23]. Sulphonylureas reduce blood glucose by increasing insulin secretion from pancreatic $\beta$-cells in patients with residual $\beta$-cell function [21]. This means that they are active in mild alloxan-induced diabetes and are inactive in intense alloxan-induced diabetes [24,25]. In this study, some alloxan-induced diabetic mice that received some extracts showed rapid normalization of blood glucose levels compared to control. This could be due to the possibility that some $\beta$-cells were still intact and were, therefore, stimulated to synthesize and release insulin by the extracts. In addition, the possibility that the extracts showed hypoglycaemic action by enhancing tissue glucose utilization cannot be ruled out in this study.

Furthermore, these extracts may have achieved hypoglycaemic activity by decreased rate of carbohydrate absorption into the portal hepatic circulation, increased glucose transport and uptake, increased glycogen storage, and modulation of insulin secretion. Shane, (2001) reported similar modes of action in his study on evaluation of hypoglycaemic potential of the aqueous leaf extract of Gymnema sylvestre. This is also the mode of action of alpha-glucosidase inhibotors such as acarbose and Miglitol [26].

The aqueous leaf extracts of B. pilosa, at higher doses (100 and $150 \mathrm{mg} / \mathrm{kg}$ body weight), failed to lower blood glucose level as effectively as the lowest dose level $(50 \mathrm{mg} / \mathrm{kg}$ body weight), which exhibited antihyperglycemic activity [Table 1]. This may have occurred due to the fact that the two dose levels ( 100 and $150 \mathrm{mg} / \mathrm{kg}$ body weight) contained a higher concentration of the extract. For this reason, the highly concentrated extract molecules took longer to be absorbed across the membranes via filtration. This is supported by the observation that in the second hour, the larger dose levels drastically lowered the blood sugar levels.

That the aqueous stem bark extracts of E. abyssinica at all dose levels, did not lower the blood glucose levels in the first hour but significantly lowered the blood glucose levels in the second, third and fourth hours may have been due to the fact that the active principles in the extract required biotransformation so as to become antihyperglycaemic. That the aqueous root bark extracts of A. pluriseta and C. edulis acted in a dose related manner could be explained by passive diffusion of the active principle across the cell membranes in the peritoneal cavity. This is because they started lowering blood sugar levels almost immediately. That the leaf extract of $S$. henningsii at a dose of $150 \mathrm{mg} / \mathrm{kg}$ body weight was not as effective as the dose level of $100 \mathrm{mg} / \mathrm{kg}$ body weight could be explained by the fact that the high dose took longer to be absorbed across the peritoneum cavity. That the dose level of $50 \mathrm{mg} / \mathrm{kg}$ body weight was not as effective as the two higher doses could be explained by the fast metabolism, clearance and inactivation of the lower concentration of the active principle. The same could be true for Catha edulis at the similar doses.

That the aqueous stem bark extract of E. abyssinica and leaf extract of $S$. henningsii at the dose of $450 \mathrm{mg} / \mathrm{kg}$ body weight, caused lymphoid depopulation in the spleen respectively, could suggest that the extract contains factors that are lymphotrophic. That the aqueous leaf extract of $B$. pilosa caused predominant diffuse vacuolar degeneration in the hepatocytes could indicate that the extract is hepatotoxic at a higher dose level. The observation that the aqueous stem bark extract of $E$. abyssinica and root bark extract of $C$. edulis caused varied kidney lesions at a dose level of $450 \mathrm{mg} / \mathrm{kgbw}$ could suggest the extracts are nephrotoxic at higher dose levels. This nephrotoxicity could have been due to the presence of saponins in this extract, which have been shown to cause contraction of the vascular system in the kidney [27]. The presence of saponins and tannins in the extracts could be the cause of hepatotoxicity observed in the study. Previous histopathological examination of rat liver sections after administration of saponins isolated from fruit extracts of Citrullus colocynthis showed that saponins cause small haemorrhage in many lobules and congestion of central veins and liver sinusoids. Moreover, destruction of the liver architecture due to the necrosis of liver cells was also seen [27]. Similarly, tannins have been associated with severe central hepatonecrosis [28].

In addition, hepatotoxicity could have been due to the presence of terpenoids in the extracts. In their study [29], found that triterpenes caused congestion in the sinusoids with centrilobular hydropic and fatty degeneration as well as hepatonecrosis. That some plants extracts shown to be toxic to mice in this study are used in herbal medicine practice without any observable toxicity could be explained by their use as combination. Further our study administered the extract at a high dose $(450 \mathrm{mg} / \mathrm{kg})$ intraperitoneally purposefully to determine the target organs of toxicity; the oral route used in traditional practice is unlikely to produce such lesions. Medicinal plants have been used in combination by traditional healers in Africa to a great extent. Traditional Chinese knowledge and practice reveals that it was usual for A.annua to be used in combination with others in the treatment of fevers [30].

In conclusion, five aqueous plant extracts from five different plants used in herbal medicine practice showed significant anti-diabetic activity. The five plant extracts from B.pilosa, A. pluriseta, E. abyssinica, C. edulis and $S$. henningsii lowered the blood sugar levels in the alloxan induced diabetic mice at the three dose levels used. Some of the five plant extracts were as effective as insulin (the reference drug) while others were more efficacious than insulin in achieving anti-diabetic activity. However, it was not possible to predict the mode of hypoglycemic effect. The classes of phytochemicals observed in these plant extracts have previously been observed to contribute to hypoglycemic effects. This study therefore supports the traditional usage of these plant extracts for the management of diabetes mellitus. This might help in preventing diabetic complications and serve as good adjuvants in the current armamentarium of antidiabetic plants.

This study recommends that the five plants should be studied further for mode of action and more comprehensive safety test with a view to developing them further in management of diabetes mellitus. Conservation of these plants is also advocated.

\section{Acknowledgement}

The authors acknowledges Kenyatta University for providing laboratory animals and the infrastructure in which this work was done. The University of Nairobi is acknowledged for histopathological analysis.

\section{References}

1. John, C. Treatment of Diabetes Mellitus with Herbs. Ann Rev of Pharmaco 1998: 13: 35-43.

2. Anonymous (2003) National Diabetes Fact Sheet United States, General Information.

3. Robert, H (2002) Diabetes Mellitus. Slim Forever International.

4. James, L. [lp-health] Prevalence of diabetes, by country 2003.

5. King H, Aubert RE, Herman WH (1998) Global burden of diabetes, 1995-2025 prevalence, numerical estimates, and projections. Diabetes Care 21:1414 1431. 
Citation: Piero NM, Joan MN, Cromwell KM, Joseph NJ, Wilson NM, et al. (2011) Hypoglycemic Activity of Some Kenyan Plants Traditionally used to Manage Diabetes Mellitus in Eastern Province. J Diabetes Metab 2:155. doi:10.4172/2155-6156.1000155

6. Anonymous (2004) Diagnosis and Classification of Diabetes Mellitus - Position Statement Diab Care 1: 27-31.

7. Krolewski AS, Warran JH, Rand LI, Kahn CR (1987) Epidemiological approach to the aetiology of type 1 diabetes mellitus and its complications. N Am J Med $331: 1428-1436$.

8. Nathan A, Sutters CA (1993) A comparison of community pharmacists' and general practitioners' opinions on rational prescribing, formularies and other prescribing related issues. J R Soc Health 113: 302-307.

9. DeFronzo RA (1999) Pharmacology therapy for type 2 diabetes mellitus. Ann Int Med 131: 281-303.

10. Huang PL, Huang P, Huang H, Lee-Huang SI (1992) Developing from traditional medicinal plants. Chem Ind 8: 290-293.

11. Kofi-Tsekpo MW, Thairu K, Mwangi JW, Njung'e K (1985) Recent advances in the management and control of infections in Eastern Africa. In: Tukei, P.M., Koech, D.K. and Kinoti, S.N. (Eds); Proceedings of the sixth annual medical scientific conference. English Press Limited. Nairobi, Kenya: 157-159.

12. Hill JB, Kessler G (1961) Automated determination of glucose oxidase peroxidase system. J Lab Clin Med 57: 970-980.

13. Houghton PJ, Raman A (1998) Laboratory handbook for the fractionation of natural extracts. Chapman and Hall:154-187.

14. Nammi S, Boini MK, Lodagala SD, Behara RB (2003) The juice of fresh leaves of Catharanthus roseus Linn. reduces blood glucose in normal and alloxan diabetic rabbits. BMC Comp Alt Med 3: 4.

15. Kimura M, Suzuki J (1985) The pharmacological role of ginseng in the blend effect of traditional Chinese medicines in hyperglycemia. Advances of Chinese Medicinal Materials Research, World Scientific, Singapore.

16. Chen KJ, Zhang WP (1987) Advances on antiageing herbal medicines in China. Ab Chin Med 1: 309-330.

17. Hson-Mou C, Paul P-HB (1986) Pharmacology and Applications of Chinese Materia Medica; (Vol II). World Scientific, Singapore.

18. Dong ZL, Yu SF (1990) Modern Study and Application of Materia Medica China Ocean Press, Beijing.
19. Bobanna KN, Kannan J, Gadgil S, Balaraman R, Rathod SP (1997) Antidiabetic and antihyperlipaemic effects of neem seed kernel powder on alloxan diabetic rabbits. Ind J Pharmacol 29: 162-167.

20. Anonymous (1998) United Kingdom Prospective Diabetes Study 24: a 6-year, randomised, controlled trial comparing sulfonylurea, insulin, and metformin therapy in patients with newly diagnosed type 2 diabetes that could not be controlled with diet therapy. United Kingdom Prospective Diabetes Study Group. Ann Int Med 128: 165-175.

21. Scott RV (2004) Diabetes Mellitus, Type 2 - A Review.

22. Singh SN, Vats $P$, Suri S, Shyan R, Kumria MML, et al. (2001) Effects of an antidiabetic extract of Catharanthus roseus on enzyme activities in streptozotocin induced diabetic rats. J Ethnopharmacol 76: 269-277.

23. Colca JR, Kotagel N, Brooks CL, Lacy PE, Landt M, et al. (1983) Alloxan inhibition of $\mathrm{Ca}^{2+}$ and Calmodulin-dependent protein kinase in pancreatic islets. J Biol Chem 225: 7260-7263.

24. Yalow RS, Black H, Villazan M, Berson SA (1960) Comparison of plasma insulin levels following administration of tolbutamide and glucose. Diabetes 9 : 356-362.

25. Grodsky GM, Epstein GH, Fanska R, Karam JH (1971) Pancreatic action of sulphonylureas. Fed Proc 36: 2719-2728.

26. Campbell LK, White JR, Campbell RK (1996) Acarbose: its role in the treatment of diabetes mellitus. Ann Pharmacother 30: 1255-1262.

27. Diwan FH, Abdel-Hassan IA, Mohammed ST (2000) Effect of saponin on mortality and histopathological changes in mice. East Medit Heal J 6: 345-351.

28. Chung KT, Wong TY, Wei Cl, Huang YW, Lin Y (1998) Tannins and human health: Review. Crit Rev Food Sci Nut 38: 421-464.

29. Zeinsteger $P$, Romero A, Teibler P, Montenegro M, Rios EM, et al. (2003) Toxicity of volatile compounds of Senecio grisebachii baker (margarita) flowers in mice. Rev Invest Agrop 32: 125-136.

30. O'Neill MJ, Bray DH, Boardman P, Chan KL, Phillipson JD, et al. (1987) Plants as sources of antimalarial drugs, Part 4: Activity of Brucea javanica fruits against chloroquine-resistant Plasmodium falciparum in vitro and against Plasmodium berghei in vivo. J Nat Prod 50: 41-48 